\title{
PENDUGAAN KELAS MUTU BUAH PEPAYA BERDASARKAN CIRI TEKSTUR GLCM MENGGUNAKAN ALGORITMA K-NEAREST NEIGHBORS
}

\author{
Feri Wibowo ${ }^{1}$, Dimara Kusuma Hakim ${ }^{2}$, Sigit Sugiyanto ${ }^{3}$ \\ ${ }^{1,2,3}$ Program Studi Teknik Informatika, Fakultas Teknik dan Sains, Universitas Muhammadiyah \\ Purwokerto, Purwokerto, Indonesia \\ e-mail: feriwibowo@ump.ac.id¹, dimarahin@yahoo.com², seagyt@gmail.com
}

\begin{abstract}
Abstrak
Proses klasifikasi mutu buah pepaya dengan cara konvensional menggunakan visual mata manusia memiliki kelemahan di antaranya yaitu membutuhkan tenaga lebih banyak untuk memilah, tingkat persepsi manusia yang berbeda, tingkat konsistensi manusia dalam menilai mutu buah tidak menjamin karena manusia dapat mengalami kelelahan. Penelitian ini bertujuan merancang dan menyusun program pengolahan citra digital dan algoritma $k$-Nearest Neighbor untuk klasifikasi pemutuan buah pepaya (Carica Papaya L) Calina IPB-9 ke dalam tiga kelas mutu yaitu kelas Super, A, dan B. Fitur tekstur yang diekstrak meliputi nilai energy, entropy, contras, homogeneity, invers difference moment, variance, dan dissimilarity yang didapatkan berdasarkan GLCM (gray level cooccurrence matrices). Fitur-fitur tersebut dijadikan sebagai input pada algoritma $k$-Nearest Neighbor untuk menghitung jarak. Hasil pengujian menggunakan jumlah $k$ tetangga 9 menunjukan tingkat akurasi sebesar $88,88 \%$.
\end{abstract}

Kata kunci: Klasifikasi, GLCM, k-Nearest Neighbor, Pepaya

\begin{abstract}
The process of classification the quality of papaya fruit in the conventional way using the visual eye of the human has the disadvantages among which is requiring more power to sort, the different levels of human perception, the level of human consistency in assessing the quality of the fruit does not guarantee because humans can experience fatigue. This research aims to design and build digital image processing application and k-Nearest Neighbor algorithm for papaya classification (Carica Papaya L) Calina IPB-9 into three class of quality that is class of Super, A, and B. Extracted texture features include energy, entropy, contrast, homogeneity, inverse difference moment, variance, and dissimilarity values obtained based on GLCM (gray level cooccurrence matrices). These features serve as inputs to the k-Nearest Neighbor algorithm for computing distances. Test results using the number of $k 9$ shows the accuracy of $88.88 \%$.
\end{abstract}

Keywords: Classficication, GLCM, k-Nearest Neighbor, Papaya

\section{PENDAHULUAN}

Berdasarkan data dari pusat data dan sistem informasi pertanian Kementrian Pertanian Republik Indoneisa tahun 2014, Produksi pepaya Indonesia tahun 2010 adalah sebesar $675.801 \mathrm{~kg}$ dan mengalami peningkatan pada tahun 2011 sebesar $958.251 \mathrm{~kg}$ kemudian produksi tahun 2012 dan 2013 berturut-turut sebesar $906.305 \mathrm{~kg}$ dan $909.818 \mathrm{~kg}$. Berdasarkan data dari pusat data dan sistem informasi pertanian Kementrian Pertanian Republik Indoneisa tahun 2014, volume ekspor pepaya tiga tahun terakhir dari tahun 2012, 2013, 2014 mengalami peningkatan dengan volume berturut-turut $25.328 \mathrm{Kg}, 25.836 \mathrm{Kg}$, dan $31.436 \mathrm{Kg}$. Berdasarkan data statistik Food \& Agriculture Organization (FAO) tahun 2000 sampai 2010 terkait dengan jumlah produksi pepaya, Indonesia merupakan salah satu 
negara penghasil pepaya dengan jumlah yang cukup besar di dunia, setelah Brazil, Meksiko, India dan Nigeria [1]. Proses sortasi merupakan salah satu proses yang sangat menentukan mutu buah pepaya yang akan dilepas ke konsumen. Selama ini identifikasi mutu dalam proses sortasi pepaya masih dilakukan secara konvensional menggunakan visual mata manusia yang memiliki keterbatasan. Proses identifikasi mutu dengan cara seperti ini memiliki beberapa kelemahan di antaranya yaitu membutuhkan tenaga lebih banyak untuk memilah, tingkat persepsi manusia dalam hal pemutuan buah yang berbeda, tingkat konsistensi manusia dalam menilai mutu buah tidak menjamin karena manusia dapat mengalami kelelahan [2].

Penelitian ini bertujuan merancang atau mendesain dan menyusun program pengolahan citra digital dan algoritma $K$ Nearest Neighbors (KNN) untuk pendugaan kelas mutu buah pepaya (Carica Papaya L) Calina IPB-9 kedalam tiga kelas mutu buah pepaya yaitu kelas Super, kelas $A$, dan kelas $B$ yang dapat dijadikan sebagai model sistem sortasi otomatis berbasis komputer. Manfaat yang diharapkan dari penelitian ini adalah dengan adanya desain model aplikasi komputer pengolahan citra digital dan algoritma K-Nearest Neighbor (KNN) yang dikembangkan, petani pepaya Calina IPB-9 dalam skala besar atau industri dipermudah dalam melakukan penyortiran buah pepaya berdasarkan kelas mutunya. Penyortiran berdasarkan mutu dilakukan supaya mendapatkan buah pepaya dengan tingkat mutu yang tepat dan seragam sehingga akan meningkatkan daya saing produk buah pepaya dengan negera-negara produsen pepaya lainnya.

Teknik-teknik pengolahan citra biasanya digunakan untuk melakukan transformasi dari satu citra kepada citra lain, sementara tugas perbaikan informasi terletak pada manusia melalui penyusunan algoritmanya [3]. Karakteristik operasi dalam pengolahan citra dapat dibedakan menjadi empat macam, yaitu operasi tingkat titik (point level), operasi tingkat lokal (local level), operasi tingkat global (global level), dan operasi tingkat obyek (object level). Tekstur dapat didefinisikan sebagai hubungan mutual antara nilai intensitas piksel-piksel yang bertetangga yang berulang di suatu area yang lebih luas daripada jarak hubungan tersebut [4]. Penelitian [5] menyebutkan analisis tekstur cukup berguna untuk mendeteksi keberadaan cacat pada kulit mangga. Analisis tekstur dapat digunakan bersamasama dengan pemeriksaan ukuran buah mangga melalui luas proyeksi pada bidang datar, untuk melakukan pemutuan terhadap mangga Arumanis berdasarkan ukuran dan keberadaan cacat pada kulitnya. Ada beberapa ciri tekstur di antaranya adalah deskriptor energi dan entropi. Deskriptor energi adalah ukuran yang menyatakan distribusi intensitas piksel terhadap jangkauan aras keabuan. Entropi mengindikasikan kompleksitas citra, semakin tinggi nilai entropi pada suatu citra, maka semakin komplek citra tersebut.

KNN adalah metode klasifikasi yang menentukan kategori berdasarkan mayoritas kategori pada $k$-tetangga terdekat. Jika $D$ adalah sekumpulan data pelatihan maka ketika data uji $d$ disajikan, algoritma akan menghitung jarak antara setiap data dalam $D$ dengan data uji $d$. penghitungan jarak dilakukan dengan menggunakan euclidian distance. Kemudian $k$ buah data dalam $D$ yang memiliki jarak terdekat dengan $d$ diambil. Himpunan $k$ merupakan $k$-nearest neighbor. Selanjutnya kategori data uji $d$ ditentukan berdasarkan label mayoritas kategori dalam himpunan $k$-tetangga terdekat [6]. Penghitungan jarak dapat dicari menggunakan euclidian distance ditunjukan pada persamaan (1)

$$
D i=\sqrt{\sum_{i=1}^{k}\left(x_{i}-y_{i}\right)^{2}}
$$

Salah satu jenis pepaya yang saat ini mulai banyak dikebunkan adalah jenis Pepaya Calina IPB-9 atau lebih dikenal dengan nama pepaya California . Pepaya Calina IPB-9 dengan ukuran antara 1200 $1300 \mathrm{~g} / \mathrm{buah}$, berkulit tebal, berbentuk lonjong buah matang berwarna kuning, rasanya manis, daging buah kenyal dan tebal. Pohon pepaya Calina merupakan 
varitas temuan Prof. Dr., Ir., Sriani Sujiprihati, MS. dari Institut Pertanian Bogor (IPB), yang merupakan pakar genetik dan pemuliaan tanaman IPB [7]. Penelitian implementasi algoritma $k$ - nearest neighbor yang berdasarkan one pass clustering untuk kategorisasi teks. Penelitian tersebut menunjukan bahwa semakin besar nilai threshold yang dipengaruhi oleh nilai epsilon, maka performa cenderung semakin menurun. Performa one pass clustering KNN lebih baik dari pada performa KNN konvensional dimana performan one pass KNN bernilai $88 \%$ pada epsilon sebesar 4 dan nilai $k$ sebesar 30 dibanding dengan performa KNN yang bernilai hanya $85 \%$ saat nilai $k=50$. [8]. [9] Melakukan perancangan dan konstruksi mesin sortasi dengan sensor kamera CCD sebagai sensor citra dan unit pengolahannya untuk melakukan evaluasi pemutuan buah jeruk. Hasilnya adalah luas area buah jeruk dapat dijadikan acuan untuk pendugaan berat buah jeruk, luas area juga dapat digunakan untuk menentukan pemutuan buah jeruk sesuai kelasnya mulai dari kelas A sampai kelas E. Penelitian karakterisasi sifat fisik jeruk manis berdasarkan tingkat ketuaan, penelitian tersebut menyimpulkan bahwa karakteristik sifat fisik jeruk manis berbeda pada klasifikasi mutu berdasarkan tingkat ketuaan dan Bobot buah berkorelasi positif dan signifikan dengan area [10]. [11] Menerapkan teknologi pengolahan citra digital dan jaringan saraf tiruan untuk mengidentifikasi mutu fisik biji pala (Myristica fragrans houtt), pengujian fisik biji pala dilakukan secara non-destruktif meliputi warna dan bentuk kemudian keluaran adalah kelas mutu biji pala yang terdiri dari mutu ABC, mutu Rimpel dan mutu BWP. Penelitian tersebut menunjukan parameter mean saturated dan area, dari hasil analisa diskriminan menunjukan parameter yang paling berpengaruh membedakan mutu pala. Berdasarkan hasil pengujian jaringan saraf tiruan dapat melakukan identifikasi dengan ketepatan hasil 100\% dari 30 jumlah sampel yang diujikan. [12] Melakukan penelitian untuk klasifikasi kematangan buah pepaya menggunakan citra warna HSV dan algoritma K-Nearest Neighbor, dan menghasilkan keakuratan sebesar $83,34 \%$.
Penelitian ini hanya melakukan klasifikasi kematangan buah pepaya tetapi tidak melakukan klasifikasi kelas mutu buah pepaya. Desain dan tujuan penelitian ini berbeda dengan penelitian sebelumnya dimana penelitian ini menggunakan algoritma k-Nearest Neighbors untuk pendugaan kelas mutu buah pepaya yang didasarkan pada ciri tekstur citra dalam hal ini adalah ciri tekstur GLCM (gray level cooccurrence matrices).

\section{METODE}

Data penelitian yang akan digunakan adalah data citra pepaya Calina IPB-9 yang berjumlah 192 buah pepaya (Carica papaya L) Calina IPB-9, dengan perincian 156 data pelatihan dan 36 data uji. Data diambil menggunakan kamera beresolusi 5MP. Pepaya yang akan dijadikan data penelitian diambil dari beberapa petani buah yang ada di kabupaten Banyumas tepatnya di daerah kecamatan Karang lewas. Penelitian ini merupakan penelitian pengembangan perangkat lunak komputer yang berfokus pada pengolahan citra digital dan algoritma K-Nearest Neighbor. Data input berupa data citra pepaya Calina IPB-9 yang berjumlah 192 data citra. Rancangan alur proses sistem pendugaan kelas mutu yang akan dibangun meliputi beberapa proses, yaitu diawali dengan proses akuisi citra, kemudian proses pengolahan citra digital yang meliputi preprocessing, segmentasi, dan proses ekstraksi ciri, kemudian data ciri disimpan di database. Data ciri akan dijadikan sebagai data input pada saat proses pendugaan kelas mutu menggunakan algoritma $K$ Nearest Neighbor. Proses akuisisi citra dilakukan pada buah pepaya Calina IPB-9 yang sudah dipetik dari pohonnya. Proses akuisisi dilakukan pada buah pepaya yang sudah dikelaskan berdasarkan kelas mutu yaitu kelas Super, kelas A, dan kelas B. Proses pengkelasan mutu ini dilakukan oleh petani pepaya yang sudah ahli dalam menilai mutu buah pepaya.

\section{Preprocessing}

Proses prepocessing dilakukan dengan tujuan supaya meningkatkan kemungkinan keberhasilan pada tahap pengolahan lebih lanjut pada sebuah citra. 
Operasi yang dilakukan pada tahap prepocessing di antaranya adalah operasi resizing dan grayscaling. Resizing adalah proses mengubah resolusi atau mengubah ukuran horizontal dan vertikal citra. Operasi resizing yang dilakukan adalah mengubah ukuran citra dari ukuran semula yaitu 3264 x 1836 pixels menjadi 1024 x 575 pixels dengan tujuan supaya mempercepat pada saat proses pengolahan citra digital, karena semakin besar ukuran citra maka akan mempengaruhi waktu yang diperlukan pada saat proses pengolahan citra digital.

\section{Segmentasi}

Segmentasi citra merupakan proses yang ditujukan untuk mendapatkan objekobjek yang terkandung di dalam citra atau membagi citra ke dalam beberapa daerah dengan setiap objek atau daerah memiliki kemiripan atribut. Pada objek yang mengandung hanya satu objek, objek dibedakan atau dipisahkan dari latar belakangnya, sehingga yang akan dilakukan pemrosesan pada tahap selanjutnya adalah bagian citra yang termasuk objek citra saja. Segmentasi dengan memilih nilai ambang(threshold) secara otomatis dapat dilakukan dengan metode Otsu. Metode ini menentukan nilai ambang dengan cara membedakan dua kelompok, yaitu objek dan latar belakang, yang memiliki bagian saling bertumpukan, berdasarkan histogram [4].

\section{Tekstur GLCM}

Ekstraksi ciri tekstur GLCM yang akan dicari menggunakan jarak $(1,0)$, yang berarti satu piksel ke kanan dan nol piksel ke bawah, atau pasangan piksel yang harus dihitung adalah yang berjarak satu piksel dengan arah sudut $0^{\circ}$.

ciri-ciri tekstur seperti energi, entropi, kontras, homogenitas, idm, variance, dissimilarity dapat dihitung berdasarkan matriks tersebut.

Definisi energi dan entropi seperti ditunjukan pada persamaan (2) dan persamaan (3).

energi $=\sum_{i=0}^{L-1} \sum_{j=0}^{L-1}\lceil p(i, j)]^{2}$ entropi $=-\sum_{i=0}^{L-1} \sum_{j=0}^{L-1} p(i, j) \log _{2}(p(i, j))$

Ciri tekstur yang lain di antaranya adalah kontras, homogenitas, invers difference moment (idm), variance, dan dissimilarity yang ditunjukan pada persamaan (4) sampai (8)

kontras $=\sum_{i=0}^{L-1} \sum_{j=0}^{L-1}(i-j)^{2}(p(i, j))$

homogenitas $=\sum_{i=0}^{L-1} \sum_{j=0}^{L-1} \frac{P(i, j)}{1+|i-j|}$

$i d m=\sum_{i=0}^{L-1} \sum_{j=0}^{L-1} \frac{1}{1+(i-j)^{2}} p(i, j)$

variance $=\sum_{i=0}^{L-1} \sum_{j=0}^{L-1}(i-\mu)^{2}(p(i, j))$

dissimilarity $=\sum_{i=0}^{L-1} \sum_{j=0}^{L-1}|i-j| p(i, j)$

\section{Nearest Neighbor}

Proses pendugaan atau klasifikasi kelas mutu buah pepaya menggunakan algoritma $k$-Nearest Neighbor yang akan dilakukan beberapa kali ujicoba menggunakan nilai $k$ bervariasi untuk mengetahui nilai akurasi yang paling baik.

Atau secara sederhana langkah-langkah algoritma KNN sebagai berikut:

1. Tentukan $k$.

2. Hitung jarak antara data baru ke setiap labeled data.

3. Tentukan $k$ labeled data yang mempunyai jarak yang paling minimal.

4. Klasifikasikan data baru ke dalam labeled data yang mayoritas.

\section{HASIL DAN PEMBAHASAN}

Citra pepaya sebagai data latih dikelompokan ke dalam tiga jenis kelas mutu, yaitu mutu Super, $A$, dan $B$, sehingga tiap kelas mutu terdapat masing-masing 56 data citra. Demikian dengan data citra uji juga akan dikelompokan ke dalam tiga jenis kelas mutu, sehingga masing-masing kelas terdapat 12 data citra. Sampel hasil akuisisi citra Pepaya Calina IPB-9 ditunjukan pada Gambar 1. 


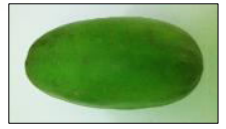

(a)

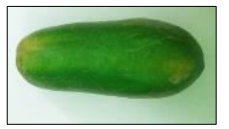

(b) (c)

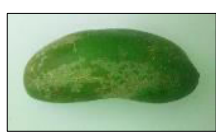

Gambar 1 Citra Pepaya Calina IPB-9; (a)

Kelas Super,(b) Kelas A, (c) Kelas B

Alur proses sistem pendugaan kelas mutu yang akan dibangun meliputi beberapa proses, yaitu diawali dengan proses akuisi citra, proses pengolahan citra digital yang meliputi preprocessing, segmentasi, dan proses ekstraksi ciri, kemudian data ciri disimpan di database. Data ciri akan dijadikan sebagai data input pada saat proses pendugaan kelas mutu menggunakan algoritma K-Nearest Neighbor.

Prinsip metode Otsu untuk mendapatkan nilai ambang ditunjukan dengan diagram alir pada Gambar 2.

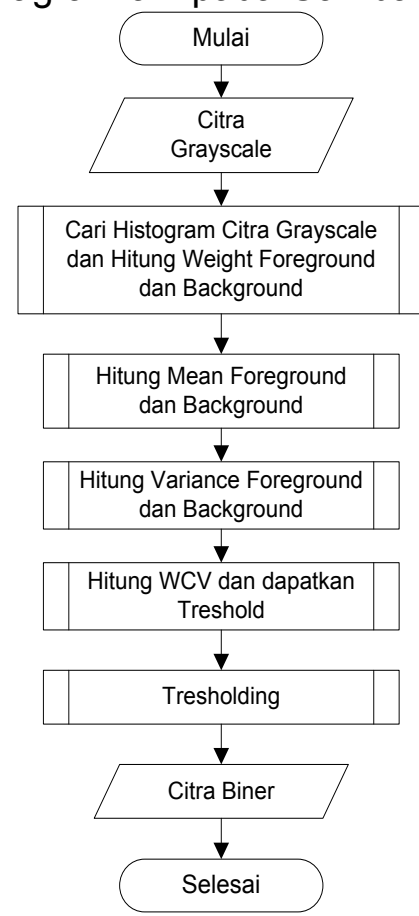

Gambar 2 Segmentasi dengan metode Otsu

Ekstraksi ciri tekstur GLCM yang akan dicari menggunakan jarak $(1,0)$, yang berarti satu piksel ke kanan dan nol piksel ke bawah, atau pasangan piksel yang harus dihitung adalah yang berjarak satu piksel dengan arah sudut $0^{0}$. Proses pendugaan atau klasifikasi kelas mutu buah pepaya menggunakan algoritma $k$-Nearest Neighbor yang akan dilakukan beberapa kali ujicoba menggunakan nilai $k$ bervariasi untuk mengetahui nilai akurasi yang paling baik.

Proses ekstraksi fitur akan menghasilkan nilai-nilai fitur tekstur GLCM di antaranya fitur energy, entropy, contras, homogeneity, idm, variance, dissimilarity. Tabel 1 menunjukan nilai rata-rata hasil ekstraksi fitur tekstur GLCM untuk tiap kelas mutu buah pepaya. Gambar 3 menunjukan grafik nila rata-rata hasil ekstraksi fitur tekstur GLCM.

Tabel 1 nilai rata-rata hasil ekstraksi fitur tekstur GLCM.

\begin{tabular}{lllcc}
\hline No. & \multicolumn{1}{c}{ Fitur } & SUPER & $\mathrm{A}$ & $\mathrm{B}$ \\
\hline 1 & Energy & 0.282 & 0.196 & 0.148 \\
2 & Entropy & 0.169 & 0.201 & 0.226 \\
3 & Contras & 0.127 & 0.130 & 0.154 \\
4 & Homogeneity & 0.937 & 0.936 & 0.925 \\
5 & Idm & 0.132 & 0.113 & 0.081 \\
6 & Variance & 0.154 & 0.133 & 0.124 \\
7 & Dissimilarity & 0.125 & 0.128 & 0.150 \\
\hline
\end{tabular}

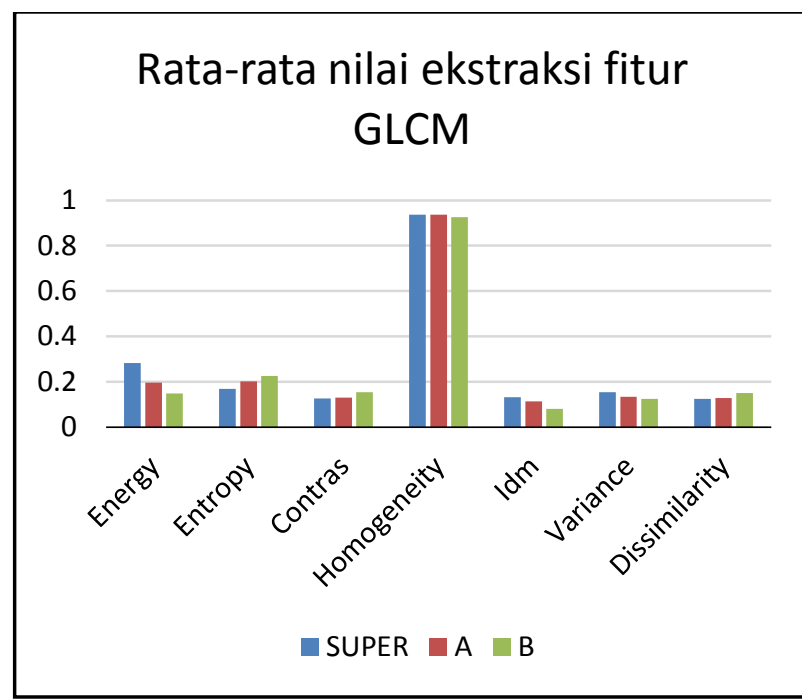

Gambar 3 gafik nilai rata-rata fitur tekstur GLCM

Pengujian sistem klasifikasi mutu Pepaya Calina IPB-9 didasarkan pada data uji. Proses pendugaan atau klasifikasi kelas mutu buah pepaya menggunakan algoritma k-Nearest Neighbor yang akan dilakukan beberapa kali ujicoba menggunakan nilai $k$ bervariasi untuk mengetahui nilai akurasi yang paling baik. Data uji berjumlah 36 data terdiri dari 12 data uji untuk tiap-tiap kelas mutu. 
Akurasi sistem klasifikasi kelas mutu pepaya dihitung dengan persamaan (9).

$$
\operatorname{akurasi}(\%)=\frac{\begin{array}{c}
\text { jumlah citra pepaya } \\
\text { dikenali sesuai kelas } \\
\text { jumlah seluruh citra } \\
\text { pepaya }
\end{array}}{\text { epara }} 100
$$


Tabel 2 Hasil pengujian terhadap data uji.

\begin{tabular}{lllll}
\hline No & $\begin{array}{l}\text { Jumlah } \\
\text { tetangga }\end{array}$ & $\begin{array}{l}\text { Dikenali } \\
\text { Sesuai } \\
\text { Kelas }\end{array}$ & $\begin{array}{l}\text { Tidak } \\
\text { Kesuai }\end{array}$ & $\begin{array}{l}\text { Dikenali } \\
(\%)\end{array}$ \\
\hline 1 & 3 & 31 & 5 & $86,11 \%$ \\
2 & 5 & 31 & 5 & $86,11 \%$ \\
3 & 7 & 31 & 5 & $86,11 \%$ \\
4 & 9 & 32 & 4 & $88,88 \%$ \\
5 & 11 & 31 & 5 & $86,11 \%$ \\
6 & 13 & 31 & 5 & $86,11 \%$ \\
\hline
\end{tabular}

Pada Tabel 2 dapat diketahui jumlah citra yang dikenali sesuai kelas. Dapat disimpulkan bahwa dengan menggunkana jumlah $k$ tetangga 9 menghasilkan nilai akurasi terbaik yaitu 32 data citra uji dikenali dan 4 data citra uji tidak dikenali sesuai kelas mutu atau tingkat akurasi sebesar 88,88 .

\section{SIMPULAN}

Berdasarkan hasil penelitian pendugaan kelas mutu buah pepaya (carica papay $L$ ) berdasarkan ciri tekstur GLCM menggunakan algoritma $k$-Nearest Neighbor dapat disimpulan proses pendugaan kelas mutu buah pepaya Calina Ipb-9 dilakukan menggunakan program yang telah berhasil dirancang dan dibuat menggunakan teknologi pengolahan citra digital untuk ekstraksi fitur tekstur GLCM citra buah pepaya dan algoritma $k$-Nearest Neighbor untuk metode klasifikasinya. Diperoleh tujuh fitur tekstur GLCM yaitu energi, entropy, contras, homogenity, idm, variance dan dissimilarity. Fitur tekstur GLCM dan algoritma k-Nearest Neighbor dapat digunakan untuk melakukan pendugaan atau pengklasifikasian mutu buah pepaya. Hasil pengujian pada Tabel 2 menunjukan nilai akurasi terbaik adalah jumlah $k$ tentangga 9 dengan nilai akurasi sebesar $88,88 \%$ Berdasarkan hasil penelitian dan kesimpulan, maka dapat diberikan saran untuk kepentingan penelitian selanjutnya adalah proses klasifikasi menggunakan metoda atau algoritma yang lain dengan harapan hasil klasifikasi yang diperoleh lebih baik lagi. Mencoba melakukan ekstraksi fitur yang lain baik dari fitur bentuk, fitur tekstur atau fitur warna, dengan harapan mendapatkan fitur dengan tingkat diskriminatif yang tinggi untuk tiap kelas mutu.

\section{UCAPAN TERIMAKASIH}

Terima kasih kepada LPPM Universitas Muhammadiyah Purwokerto yang telah membiayai peneletian ini sehingga dapat selesai dan semoga dapat bermanfaat bagi masyarakat.

\section{DAFTAR PUSTAKA}

[1] Economic and Social Development Department, FAO., 2010, Medium-term prospects for agricultural commodities (Tropical Fruits), http://www.fao.org/docrep/006/y5143e/y 5143e1a.htm, diakses 28 April 2016.

[2] Syaefullah, E., Purwadaria, H.K., \& Sutrisno, 2011, Pengolahan Citra Digital dan Jaringan Saraf Tirua untuk Identifikasi Tingkat Ketuaan Pepaya, Prosiding Seminar Nasional Teknologi Inovatif Pascapanen Pertanian III, ISBN: 978-979-1116-32-9, Bogor.

[3] Ahmad, U., 2005, Pengolahan Citra Digital \& Teknik Pemrogramannya, Graha Ilmu, Yogyakarta.

[4] Kadir, A. \& Susanto, A. 2013, Teori dan Aplikasi Pengolahan citra, Penerbit Andi, Yogyakarta.

[5] Ahmad, U., 2002, Pengolahan Citra untuk Pemeriksaan Mutu Buah Mangga, Buletin Keteknikan Pertanian, Fakultas Teknologi Pertanian IPB, Bogor

[6] Farsiah, L., Abidin, T.F., \& Munadi, K., 2013, Klasifikasi gambar berwarna menggunakan k-nearest neghbor dan support vector machine, SNASTIKOM, Banda Aceh.

[7] BLST (Bogor life Science and Technology), 2015, Pepaya Calina IPB 9, http://b/st.co.id/pepaya-calina-ipb-9, diakses 17 November 2016. 
[8] Arifin, A.D., Arieshanti, I., \& Arifin, A.Z., 2012, Implementasi algoritma k-nearest neighbor yang berdasarkan one pass clustering untuk kategorisasi teks, ITS, Surabaya.

[9] Ahmad, U., Tjahjohutomo, R., \& Mardison, 2008, Perancangan dan Konstruksi Mesin Sortasi dan Pemutuan Buah Jeruk dengan Sensor kamera CCD, Junal Keteknikan Pertanian (JTEP), ISSN 0216-3365, Bogor.

[10] Adnan, 2011, Karakteristik sifat jeruk manis berdasarkan tingkat ketuaan, Prosiding seminar teknologi inovatif pascapanen pertanian ISBN: 978-979116-32-9, Bogor
[11] Dinar, L., Suyantohadi, A., dan Fallah, M.A.F., 2012. Pendugaan Kelas Mutu Berdasarkan Analisa Warna dan Bentuk Biji Pala (Myristica Fragnans Houtt) Menggunakan Teknologi Pengolahan Citra Digital dan Jaringan Syaraf Tiruan, Junal Keteknikan Pertanian (JTEP) Vol. 26. No.1 April 2012, ISSN 0216-3365, Bogor.

[12] Sugiyanto, S, \& Wibowo, F., 2015, Klasifikasi Tingkat Kematangan Buah Pepaya (Carica Papaya L) California (Callina-Ipb 9) Dalam Ruang Warna Hsv dan Algoritma K-Nearest Neighbors, Seminar NasionalHasil-Hasil Penelitian dan Pengabdian LPPM Universitas Muhammadiyah Purwokerto. 